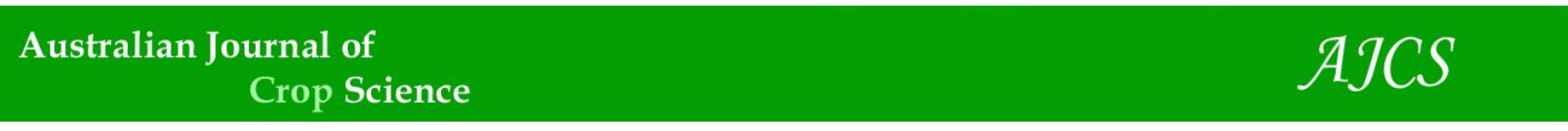

AJCS 12(07):1051-1057 (2018)

ISSN:1835-2707

doi: 10.21475/ajcs.18.12.07.PNE809

\title{
Cryopreservation of Brazilian orchid (Catasetum atratum Lindl.) seed at risk of extinction
}

\author{
Ana Beatryz Prenzier Suzuki ${ }^{1 *}$, Thaís Cristina Morais Vidal ${ }^{1}$, Guilherme Augusto Cito Alves ${ }^{1}$, Douglas \\ Bertoncelli Junior ${ }^{1}$, Guilherme Biz ${ }^{2}$, Mauren Sorace ${ }^{3}$, Ricardo Tadeu de Faria ${ }^{1}$ \\ ${ }^{1}$ Universidade Estadual de Londrina, Centro de Ciências Agrárias, Departamento de Agronomia. Londrina/PR, Brazil \\ ${ }^{2}$ Universidade Estadual de Londrina, Centro de Ciências Exatas, Departamento de Estatística. Londrina/PR, Brazil \\ ${ }^{3}$ Universidade Estadual de Maringá, Brazil
}

*Corresponding author: ana.suzuki@live.com

\begin{abstract}
The Brazilian orchid (Catasetum atratum) is a species that exist in Cerrado and in the Atlantic Forest environments, considered as areas of hotspot. The threats are arising from the risk of excessive collection because of its medicinal value may lead the species to become endangered in the near future. Cryotechnology has gained notoriety for conservation and preservation of endangered plant species, either through cryopreservation of the seeds or its parts such as: embryos, pollen, tissues and cells. The purpose of this study is to evaluate effect of different cryoprotectants through liquid nitrogen cryopreservation on endangered Brazilian Orchid Catasetum atratum seeds. The study consists of two control treatments: C1 -control without immersion in cryoprotectant solution and without liquid nitrogen; and C2 - no cryoprotectant and only liquid nitrogen. The other treatments with cryoprotectant solutions were: glycerol, sucrose, PVS2 and phloroglucinol isolated and combined. The experimental design was completely randomized design with two controls, 11 treatments and 10 replications. The data were subjected to analysis of variance and averages compared by Tukey test at $p \leq 0.05$. The seeds showed the initial embryo viability of $69.7 \pm 3.30 \%$ at $\mathrm{C} 1$ (control) condition. The seeds with PVS2, glycerol + PVS2 and and sucrose + PVS2 + 1\% of phloroglucinol were those, which presented higher viability of $67.7 \%, 66.1 \%$ and $69.8 \%$, respectively, after cryopreservation. The survival of protocorms stood out as $62.0 \%$ (PVS2) and $65.4 \%$ (+ $1 \%$ sucrose phloroglucinol). The PVS2 solution was the one which improved seed survival and seedling germination of $C$. atratum (67.7\%) with no abnormality.
\end{abstract}

Keywords: cryoprotectant, liquid nitrogen, Orchidaceae, vitrification.

Introduction

The sub-tribe Catasetinae is unique in the America. Its distribution occurs from Mexico to northern Argentina and Bolivia, with the vast majority of species represented in South America (Faria et al., 2016). The largest occurrence of this genus is in Brazil with 103 valid species (Barros et al., 2015). The Catasetuns are mostly epiphytes but also terrestrial or lithophytic (Holst, 1999). The species Catasetum atratum Lindley. (Fig 1) occurs in Cerrado and in the Atlantic Forest in the states of Minas Gerais, São Paulo, Paraná, Santa Catarina and Rio Grande do Sul.

According to Faria et al. (2016), C. atratum have early flowering, upright inflorescences at the base and arched in the upper third; waxy flowers, distributed in the upper third; upright, parallel antennas of average size, reaching the bottom of the bag of the Labellum; green sepals lanceolate, concave, with dense dark-red macules case; concave petals, lanceolate, green with large macules more notable dark-red; upper lip, trilobed, helmet-shaped, apex facing backwards, and side-lobe margins median lobes with sensitive fringes. The apex and the inner side of the cavity are whitish.

This species has a large extent of occurrence but the threats arise from the risk of indiscriminate collection because of its ornamental and medicinal value. This may cause the species to be placed in threatened category in the near future. The Conselho Nacional de Conservação da Flora (National Council for the Conservation of Flora) - CNCFlora (2016) classified this species as nearly threatened with extinction (NT): species that currently do not qualify as threatened, but are close or susceptible of being classified in a category of threat in the near future.

The continuous destruction of natural habitats of this genus jeopardizes its existence, which justifies more detailed studies on conservation and cryopreservation of $C$. atratum, contributing to the understanding of these issues. Therefore, more information about the genus and species can assist the chances of its preservation in the near future if there is need to reintroduce them into their natural habitats, with high chances of success. The cryopreservation technology is as a efficient method for conservation of this germplasm.

Galdiano Júnior (2013) indicated that the cryostorage of seeds in liquid nitrogen (NL) was initially developed for conservation of genetic resources of species with agricultural importance. However, this technology has gained great prominence in recent years in the preservation 
of endangered plant species, with the cryopreservation of seeds and other parts as embryos, pollen, tissues and cells.

The basic principle of cryopreservation is temperature reduction to slow down the cell metabolism, allowing seeds and tissues to be kept for indeterminate periods, and the resumption of normal cell development after storage in liquid nitrogen at $-196^{\circ} \mathrm{C}$ (Pegg, 2007).

The key to successful cryopreservation involves the need for rigorous control procedures for dehydration, cryoprotectant permeability and the prevention of injuries caused by osmotic stress and toxicity of chemical components of cryoprotectant solutions during dehydration (Vendrame et al., 2014).

The purpose of this study is to evaluate the influence of different cryoprotectants on cryopreservation through liquid nitrogen (LN) of Brazilian orchid seeds Catasetum atratum.

\section{Results and Discussion}

\section{Survival of seeds after freezing}

The seeds of Catasetum atratum used in this experiment showed $69.7 \pm 3.30 \%$ of viability without undergoing the process of cryopreservation. The seeds contained wellformed embryos when observed in stereo magnifier, and it was possible to assess their viability due to the red coloring obtained by the tetrazolium test (Fig 1). The initial water content was $7.02 \%$.

The seeds stored in PVS2 (T4), glycerol + PVS2 (T6) and sucrose + PVS2 $+1 \%$ of phloroglucinol (T9) were those which presented higher viability of $67.7 \%, 66.1 \%$ and 69.8 $\%$, respectively, after cryopreservation. There was no statistical difference from control (C1), which featured a 69.7 $\%$ survival rate. Survival was determined by the viability test with $1 \%$ tetrazolium.

Carneiro (2014), tested the survival of seven different species of orchids native to Cerrado using cryoprotectant solutions of glycerol, sucrose and PVS2 alone or combined. He obtained the following survival rate in treatments that did not use cryoprotectant solutions: Cyrtopodium sainttlegerianum (70.15\%), Cyrtopodium eugenii (59.55 \%), Epidendrum secundum (69.15\%), Epidendrum nocturnum (31.86\%), Epidendrum desciflorum (42.85\%), Cohniella cepula (63.62 \%), Lockhartia goyazensis (51.99\%). For these species cryoprotectants were not effective. The experiment demonstrated that these plants do not need a cryoprotectant before immersion in liquid nitrogen. On the other hand, Souza (2015) concluded that the use of cryoprotectant was important to the preservation of seeds of Lonopsis utricularioides. The most appropriate treatment was performed with glycerol $2 \mathrm{M}$ with $0.4 \mathrm{M}$ sucrose (20 $\mathrm{min}$ ) and PVS2 (10 $\mathrm{min})$.

The long-term seed storage in liquid nitrogen is the simplest and most effective method for the ex situ conservation of plant genetic resources (González-Benito and Pérez-García, 2001). This method is an alternative to traditional seed bank, where there is often a deterioration of seeds (Pérez-García and Gonzalez-Benito, 2008).

\section{Formation of protocorms}

The formation of protocorms at 180 days after germination (DAG) presented statistically similar results to the tetrazolium test. Survival was higher in protocorms of treatments T4 with $62.0 \%$, and T9 with $65.4 \%$. Also, it did not differ from the treatment $\mathrm{C} 1$, which was $65.5 \%$. The treatment 6 did not get good results on survival of protocorms (37.2\%) despite of achieving high seed viability, when exposed to the tetrazolium. Consequently, the formation of plantlets will not occur, the reason that such treatment is not recommended for this species. The seeds subjected to the cryoprotectants of treatments $\mathrm{C} 2, \mathrm{~T} 1, \mathrm{~T} 2$ and T3 showed no survival of the protocorms.

Table 1 shows that PVS2 is more effective for this kind of orchid than the other cryoprotectant treatments/solutions. The treatments with the highest percentage of survival were those which had the PSV2 formula, though combined with other cryoprotectants (glycerol and/or sucrose) with negative effect. The high concentration of these solutions caused toxicity to the cryopreserved cells, resulting in low survival of embryos after defrosting. The treatments C2, T1, T2, and T3 did not initiate development of protocorms.

Vendrame and Faria (2011), working with protocorms of Dendrobium nobile, obtained different results for this type of tissues. The highest survival rates were obtained with protocorms treated with glycerol $2 \mathrm{M}+1 \%$ with PVS2 phloroglucinol. The same authors also found that plants developed from these protocorms do not present abnormality in their development. The T7 treatment with the same combination of solutions did not present satisfactory results for seeds, both showed the survival rate of $(48.2 \pm 3.77)$ in the phytometric and dry mass analyzes. It is likely that this occurred because the seed have less water than the protocorm. Thereby, the cryoprotectants were applied to remove water from the cell to prevent the formation of ice crystals. Dehydration was too intense in the case of the seed, interfering with the vital activity of the cells. The protocorms contain more water (hydrated), which is necessary for a successful recovery after cryopreservation.

\section{Phytometric analysis}

The height of the shoot in the treatment $\mathrm{T} 4$ presented results statistically similar to treatment $\mathrm{C} 1,3.16 \pm 0.31$ and $0.51 \pm 3.65 \mathrm{~cm}$, respectively, differing from other treatments. The dry mass of the aerial part presented the same pattern of results, with average of $16.80 \pm 2.33 \mathrm{mg}$ for control treatment 1 and $14.57 \pm 1.42 \mathrm{mg}$ for treatment 4 (PVS2), showing no difference among one another.

The roots had higher growth in T8 and T9, $8.41 \pm 0.54 \mathrm{~cm}$ and $9.85 \pm 0.50 \mathrm{~cm}$, respectively, with similarity in the dry mass of the root (MSR) as can be seen in Table 2. However, comparing the development of the aerial part to the root, it is possible to notice a highly abnormal amount during the development process of these treatments (T8 and T9).

\section{Evaluation of the aerial part and roots}

The Rules of Seed Analysis (Brasil, 2009) explain seedlings with small defects and abnormalities in their original structures, when they show a satisfactory and balanced development when compared with other intact seedling of the similar test. According to Index of the shoot-root ratio in Fig 2 , it is possible to find which treatments were closer 
Table 1. Survival of Catasetum atratum subjected to different cryoprotectant solutions soon after defrosting and at 180 DAG through the formation of protocorms.

\begin{tabular}{lcc}
\hline & \multicolumn{2}{c}{ Survival seeds (\%) } \\
\cline { 2 - 3 } Treatments & TTZ after thawing & $\begin{array}{c}\text { Formation of protocorms } \\
\text { (180 DAG) }\end{array}$ \\
\hline C1 - without cryoprotectant and without immersion & $69.7 \pm 3.30 \mathrm{a}$ & $65.5 \pm 2.51 \mathrm{a}$ \\
in NL & & - \\
C2 - unsolved cryoprotectant & $7.6 \pm 1.77 \mathrm{f}$ & - \\
T1 - G 2M & $9.6 \pm 1.90 \mathrm{f}$ & - \\
T2 - S 0.4 M & $10.6 \pm 1.78 \mathrm{f}$ & - \\
T3 - G 2M + S 0.4 M & $10.5 \pm 1.35 \mathrm{f}$ & $62 \pm 1.63 \mathrm{ab}$ \\
T4 - PVS2 & $67.7 \pm 2.91 \mathrm{ab}$ & $36.8 \pm 2.20 \mathrm{~d}$ \\
T5 - PVS2 + 1 \% FL & $41.9 \pm 2.33 \mathrm{e}$ & $37.2 \pm 2.78 \mathrm{~d}$ \\
T6 - G 2 M + PVS2 & $66.1 \pm 3.31 \mathrm{ab}$ & $39.0 \pm 205 \mathrm{~d}$ \\
T7 - G 2 M + PVS2 + 1\% FL & $48.2 \pm 3.77 \mathrm{~d}$ & $61.6 \pm 3.06 \mathrm{~b}$ \\
T8 - S 0.4 M + PVS2 & $64.4 \pm 3.03 \mathrm{bc}$ & $65.4 \pm 3.13 \mathrm{a}$ \\
T9 - S 0.4 M + PVS2 + 1 \% FL & $69.8 \pm 2.66 \mathrm{a}$ & $39.1 \pm 2.33 \mathrm{~d}$ \\
T10 - G 2 M + S 0.4 M + PVS2 & $43.4 \pm 3.27 \mathrm{e}$ & $55.6 \pm 2.50 \mathrm{c}$ \\
T11 - G 2 M + S 0.4 M + PVS2 + 1 \% FL & $61.4 \pm 3.41 \mathrm{c}$ & 4.88 \\
\hline CV (\%) & 6.32 & \\
\hline
\end{tabular}

${ }^{*} \mathrm{TTZ}=$ tetrazolium salt test done soon after the withdrawal of the seeds from liquid nitrogen to verify the viability of seeds; DAG = days after germination. Averages in column followed by the same letter do not differ by Tukey test $(p \leq 0.05)$.

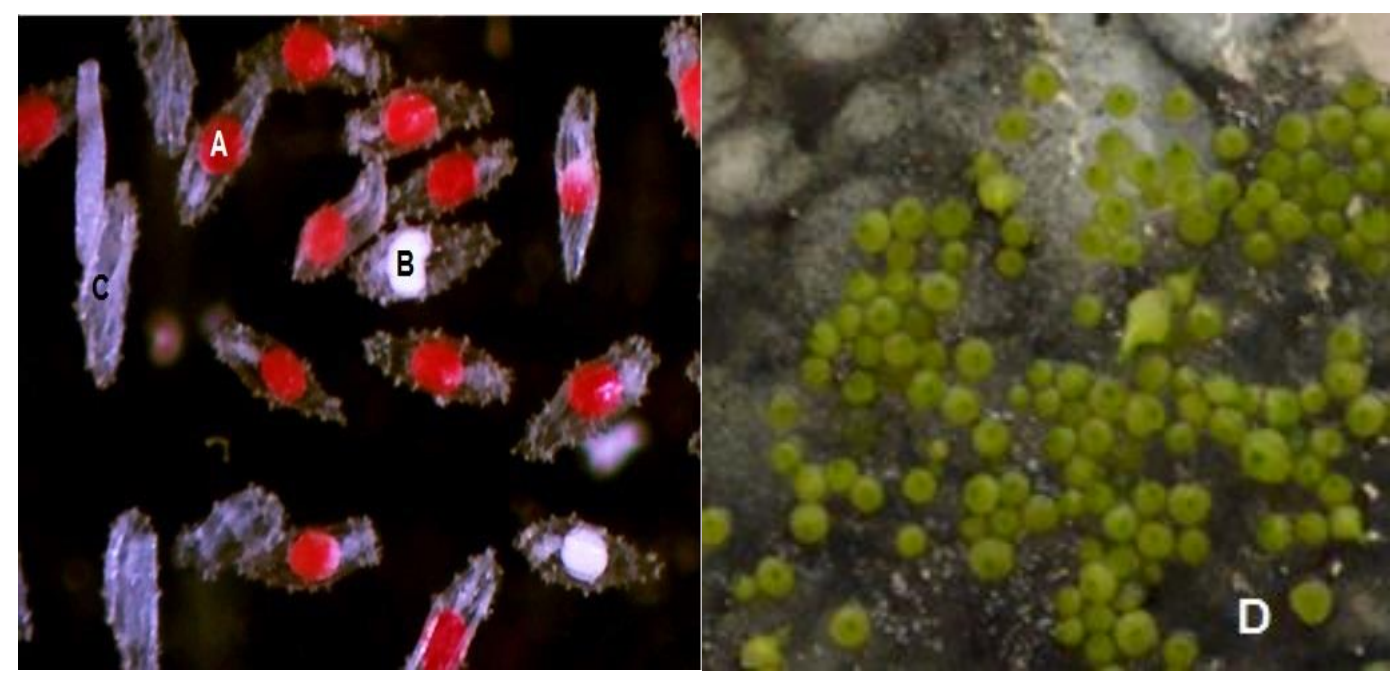

Fig 1. Seeds of Catasetum atratum preserved in PVS2 solution and subsequently submitted to the tetrazolium test to verify the survival of the embryo: (A) viable embryo; (B) non-viable embryo; (C) no seed embryo; (D) preserved seed germination in PVS2 solution forming the protocorms after 180 days of germination.

Table 2. Height of the air (HA), aerial dry mass (AD), length of root (LR) and root dry mass (RD) Catasetum atratum 360 days after germination (DAG), referring to the treatments with and without different cryoprotectant solutions.

\begin{tabular}{lllll}
\hline \multirow{2}{*}{ Treatments } & $\mathrm{HA}(\mathrm{cm})$ & $\mathrm{AD}(\mathrm{mg})$ & $\mathrm{LR}(\mathrm{cm})$ & $\mathrm{RD}(\mathrm{mg})$ \\
\cline { 2 - 5 } & $360 \mathrm{DAG}$ & & & \\
\hline C1 - without cryoprotectant & & & \\
immersion in NL & & & & \\
T4 - PVS2 & $35.72 \pm 3.55 \mathrm{c}$ & \\
T5 - PVS2 + 1\% PL & $3.16 \pm 0.31 \mathrm{a}$ & $14.57 \pm 1.42 \mathrm{a}$ & $3.00 \pm 0.12 \mathrm{c}$ & $14.48 \pm 0.58 \mathrm{~d}$ \\
T6 - G 2 M + PVS2 & $0.52 \pm 0.03 \mathrm{de}$ & $2.41 \pm 0.15 \mathrm{de}$ & $0.21 \pm 0.17 \mathrm{f}$ & $1.00 \pm 0.83 \mathrm{~g}$ \\
T7 - G 2 M + PVS2 + 1\% PL & $0.32 \pm 0.07 \mathrm{e}$ & $1.47 \pm 0.32 \mathrm{e}$ & $1.49 \pm 0.13 \mathrm{~d}$ & $7.19 \pm 0.63 \mathrm{e}$ \\
T8 - S 0.4 M + PVS2 & $0.53 \pm 0.15 \mathrm{de}$ & $2.45 \pm 0.69 \mathrm{de}$ & $3.45 \pm 0.34 \mathrm{c}$ & $16.65 \pm 1.63 \mathrm{~d}$ \\
T9-S 0.4 M + PVS2 + 1\% PL & $1.62 \pm 0.15 \mathrm{~b}$ & $7.47 \pm 0.68 \mathrm{~b}$ & $8.41 \pm 0.54 \mathrm{ab}$ & $69.78 \pm 5.96 \mathrm{a}$ \\
T10 - G 2 M + S 0.4 M + PVS2 & $0.66 \pm 0.20 \mathrm{~d}$ & $3.05 \pm 0.93 \mathrm{~d}$ & $9.85 \pm 0.50 \mathrm{a}$ & $47.58 \pm 2.43 \mathrm{~b}$ \\
T11 - G 2 M + S 0.4 M + PVS2 + 1\% PL & $0.87 \pm 0.29 \mathrm{~cd}$ & $4.02 \pm 1.33 \mathrm{~cd}$ & $0.52 \pm 0.12 \mathrm{e}$ & $2.52 \pm 0.58 \mathrm{f}$ \\
\hline CV (\%) & $1.75 \pm 0.86 \mathrm{bc}$ & $8.04 \pm 3.99 \mathrm{bc}$ & $8.35 \pm 0.66 \mathrm{~b}$ & $49.33 \pm 1.85 \mathrm{~b}$ \\
\hline
\end{tabular}

${ }^{*}$ The treatments $\mathrm{C} 2, \mathrm{~T} 1, \mathrm{~T} 2$ and T3 were not included in the Table since plant materials did not survive. Averages in column followed by the same letter do not differ by Tukey test $(\mathrm{p} \leq 0.05)$. Min at $25^{\circ} \mathrm{C}$ and subsequently removed the solution and added PVS2 solution with or without $1 \%$ of phloroglucinol for 10 min at $0{ }^{\circ} \mathrm{C}$. 


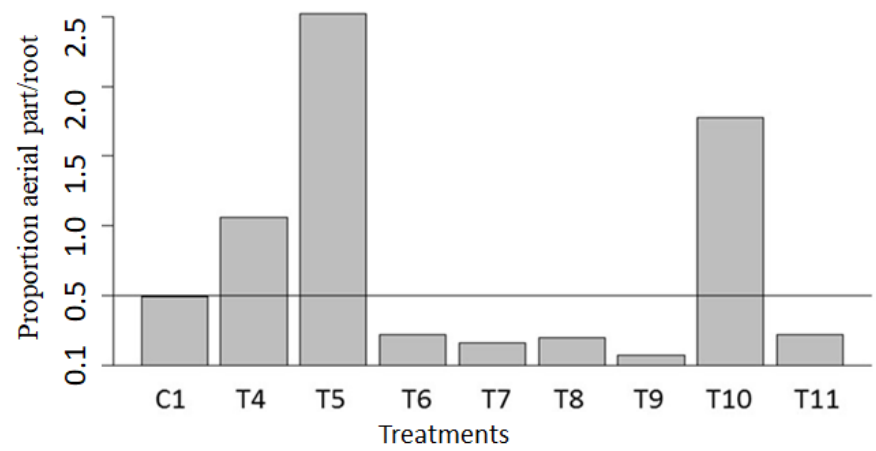

Fig 2. Index of the shoot-root ratio of seedlings of Catasetum atratum 360 days after thawing. Plants with proportions closest to $1: 2$ (0.5) have higher probability of development.

Table 3. Composition of cryoprotectant solutions treatments used for cryopreservation of seeds Catasetum atratum.

\begin{tabular}{|c|c|c|}
\hline Treatments & Composition of solutions & $\begin{array}{l}{ }^{*} \text { Exposure time and } \\
\text { temperature }\end{array}$ \\
\hline C1 & Without cryoprotectant; without immersion in $\mathrm{NL}$ & - \\
\hline $\mathrm{C} 2$ & Without cryoprotectant; & - \\
\hline $\mathrm{T} 1$ & G $2 \mathrm{M}$ & $25^{\circ} \mathrm{C}-20 \mathrm{~min}$ \\
\hline $\mathrm{T} 2$ & S $0.4 \mathrm{M}$ & $25^{\circ} \mathrm{C}-20 \mathrm{~min}$ \\
\hline T3 & $\mathrm{G} 2 \mathrm{M}+\mathrm{S} 0.4 \mathrm{M}$ & $25^{\circ} \mathrm{C}-20 \mathrm{~min}$ \\
\hline $\mathrm{T} 4$ & PVS2 & $0^{\circ} \mathrm{C}-10 \mathrm{~min}$ \\
\hline T5 & PVS2 + $1 \%$ PL & $0^{\circ} \mathrm{C}-10 \mathrm{~min}$ \\
\hline T6 & G $2 M+P V S 2$ & $25^{\circ} \mathrm{C}-20+\min 0{ }^{\circ} \mathrm{C}-10 \min$ \\
\hline $\mathrm{T7}$ & $\mathrm{G} 2 \mathrm{M}+1 \%+\mathrm{PVS} 2 \mathrm{PL}$ & $25^{\circ} \mathrm{C}-20+\min 0{ }^{\circ} \mathrm{C}-10 \mathrm{~min}$ \\
\hline T8 & S $0.4 \mathrm{M}+\mathrm{PVS} 2$ & $25^{\circ} \mathrm{C}-20+\min 0{ }^{\circ} \mathrm{C}-10 \min$ \\
\hline T9 & S $0.4 \mathrm{M}+\mathrm{PVS} 2+\mathrm{PL}$ & $25^{\circ} \mathrm{C}-20+\min 0{ }^{\circ} \mathrm{C}-10 \min$ \\
\hline T10 & $\mathrm{G} 2 \mathrm{M}+\mathrm{S} 0.4 \mathrm{M}+\mathrm{PVS} 2$ & $25^{\circ} \mathrm{C}-20+\min 0{ }^{\circ} \mathrm{C}-10 \min$ \\
\hline $\mathrm{T} 11$ & $\mathrm{G} 2 \mathrm{M}+\mathrm{S} 0.4 \mathrm{M}+1 \%+\mathrm{PVS} 2 \mathrm{PL}$ & $25^{\circ} \mathrm{C}-20+\min 0^{\circ} \mathrm{C}-10 \min$ \\
\hline
\end{tabular}

$\mathrm{C}=$ control; $\mathrm{T}=$ treatment; $\mathrm{G}=$ glycerol; $\mathrm{S}=$ sucrose; PVS2 = Plant vitrification solution 2; PL = phloroglucinol; NL = Liquid Nitrogen; ${ }^{*}$ Treatments consisting of two temperatures and two exposure time were first subjected to glycerol and/or sucrose, 20.

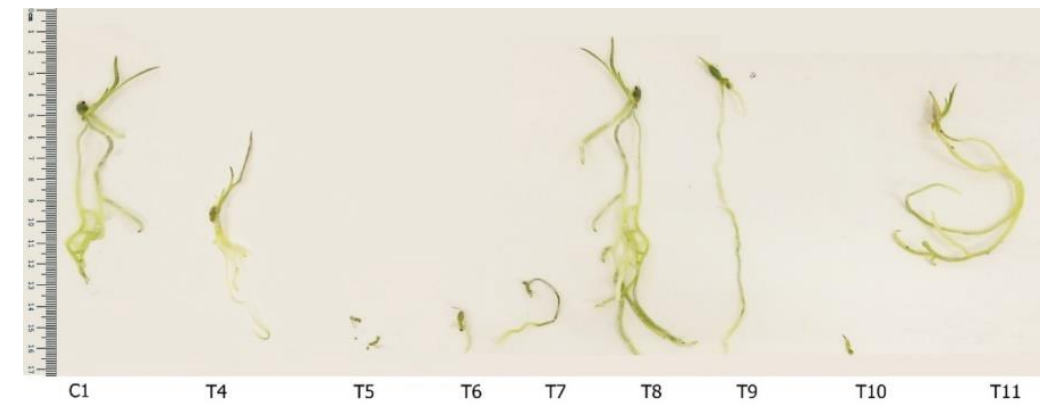

Fig 3. Seedlings of Catasetum atratum obtained from seeds preserved at different cryoprotectant treatments, 360 days after germination (DAG).

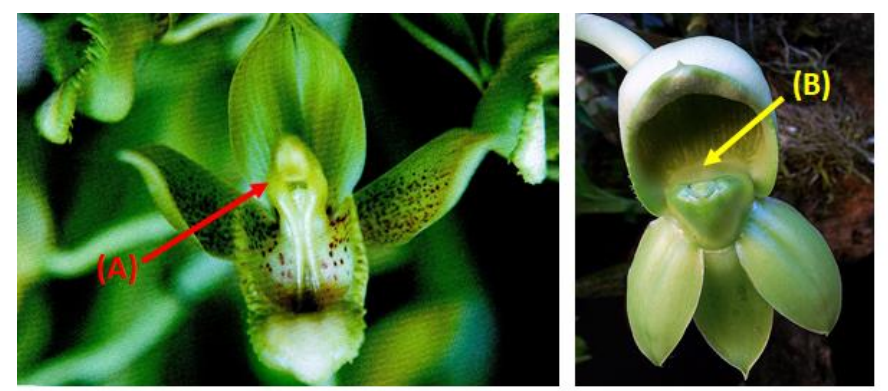

Fig 4. Detail of the Flowers of Catasetum atratum. The male flower (right): (A) anther. The female flower (left): (B) stamen. 
closer to the considered normal development (1:2; shoot:root).

In some of the cryoprotectant treatments the $C$. atratum seedlings did not show full development (Fig 3). Compared to control 1 (C1), the non-development of seedlings in treatments T5, T6, T7 and T10; and the over-development of the roots and reduced aerial part in treatments T8, T9 and T11 are noticeable.

Taiz and Zeiger (2004) described that plants grown in the presence of ethylene have increased root elongation. This fact may also be related to the biosynthesis of indoleacetic acid (IAA), because the biosynthesis of IAA is related to tissues that grow and develop quickly. Kerbauy (2008) noted that in plants grown in vitro certain conjugations facilitate the growth of the aerial part, but not the roots, while others have opposite effect, as occurred in the roots of $C$. atratum.

Covalent conjugation of amino acids with the IAA can result in permanent inactivation. However, most of the conjugations of amino acid act reserve, from which the IAA can be quickly released by enzymatic processes. The indolyl3-butyric acid (IBA) is a compound that occurs naturally in plants and also a source of auxin to specific development processes. This acid is easily converted to IAA for $\beta$-oxidation and routinely used as a rooting mechanism (Taiz and Zeiger, 2004).

In conventional in vitro cultivation, the seedlings are grown in sealed bottles preventing gas exchange. This method possess high relative humidity ( $\pm 98 \%$ ), high concentrations of ethylene, low $\mathrm{CO}_{2}$ concentration (less than $100 \mu \mathrm{mol} \mathrm{mol}{ }^{-1}$ in luminous period), low photosynthetic photon flux density $\left(40-50 \mu \mathrm{mol} \mathrm{m} \mathrm{s}^{-1}\right)$ with sucrose as the main source of metabolic energy (Arigita et al., 2002).

The high concentrations of sugars in the cryoprotectans, combined with the sucrose present in the growth medium, were toxic to the seeds leading to an abnormal development of the plants. Despite this, it is possible to affirm that these solutions have caused the production of growth hormones through physiological changes in seeds. In some species, the auxins conjugates to complex glucans (multiple units of sugar) or glycoproteins, but it is not yet known the exact physiological role of these conjugates as describes Taiz and Zeiger (2004).

Another factor that may be related to excessive development of roots is the growing conditions (temperature, relative humidity and luminosity). Ferreira (2014) worked with in vitro cultivation of three different Orchid: Cattleya warneri, Epidendrum secundum and a cross of Encyclia pauciflora x Encyclia osmantha. That experiment was based on how the environmental changes affect the cultivation. She grew the plants in the greenhouse and in controlled environment growth room, using glass jars with lids for both. One of the results obtained by the author was that species $C$. warneri showed no difference for root dry mass between the treatments. However, for E. pauciflora $\mathrm{x}$ E. osmantha the growth room showed a greater effect in growth of root than the seedlings developed in the greenhouse. The E. secundum also gained a greater root development in growth room. Therefore, techniques of tissue culture and micropropagation in vitro are useful tools for many purposes and can be used according to the needs of each species (Carneiro, 2014).

It must be considered that cryoprotectants are chemicals that reduce the injury suffered by the cell during freezing and thawing processes. The most commonly used compounds are propylene glycol, ethylene glycol, methanol, glycerol and dimethyl sulfoxide (DMSO). They are and able to pass through the cell membranes. However, these cryoprotectants can be toxic or may cause osmotic stress, causing the cells to die or to modify their response to morphogenetic culture (Day and Mclellan, 1995). That would be another factor, explaining the excessive growth of roots in PVS2 treatments, which is a solution composed of ethylene glycol, glycerol and DMSO.

Cryopreservation methods allow the conservation of plant genetic resources for long periods, though it is a very detailed process and offers some risks with respect to access to plant material and the resumption of development when not done properly (Pilatti et al., 2010).

\section{Materials and Methods}

\section{Description of plant material}

The seeds of Catasetum atratum Lindl. were obtained by artificial pollination of plants cultivated in the greenhouse of the Department of Agronomy of Universidade Estadual de Londrina. The flowers (Fig 4) were pollinated a week after anthesis, and ripe capsules were harvested seven months after pollination.

The closed capsules were disinfested with $3 \%$ sodium hypochlorite solution for 20 minutes. The capsules were opened and the seeds removed in laminar flow chamber. The moisture content was adjusted by oven at $105 \pm 3{ }^{\circ} \mathrm{C}$ according to specifications of the Rules for Seed Analysis, as well as the initial viability of seeds through the tetrazolium test (Brasil, 2009). The tetrazolium test was carried out by placing the seeds in water for 24 hours at $25{ }^{\circ} \mathrm{C}$ to be hydrated. Then, the water was removed and added to $1 \%$ tetrazolium solution. The seeds remained for additional 24 hours under a temperature of $30{ }^{\circ} \mathrm{C}$, after which their feasibility and viability were assessed with the aid of a magnifying glass and stereoscopic software Motic Images Plus 2.0 ML.

\section{Description of cryoprotectant solutions and protocol}

The treatments consisted of soaking the seeds in different cryoprotectant solutions according to Table 3 . For each treatment, $5 \mathrm{mg}$ of seeds were placed in cryotubes with a capacity of up to $2.0 \mathrm{~mL}$. In control 1 (C1), the seeds were removed from the cryotubes and germinated immediately, without cryoprotectant treatment or immersion in NL. In control 2 (C2) seeds were immersed in nitrogen, without adding any cryoprotectant substance.

The other treatments consisted of $2 \mathrm{~mL}$ of one of the different cryoprotectant solutions. T1, T2 and T3 were exposed to solutions for 20 minutes at the temperature of $25^{\circ} \mathrm{C}$. For treatments $\mathrm{T} 4$ and $\mathrm{T} 5$, which contained the PVS2 solution, the seeds were exposed for 10 minutes to $0{ }^{\circ} \mathrm{C}$. In treatments $\mathrm{T} 6, \mathrm{~T} 7, \mathrm{~T} 8, \mathrm{~T} 9, \mathrm{~T} 10$ and $\mathrm{T} 11$ seeds were soaked for 20 minutes at $25 \pm 2{ }^{\circ} \mathrm{C}$ in the solutions containing glycerol, sucrose and glycerol + sucrose, and then removed and placed in the solutions containing PVS2 and PVS2 + $1 \%$ $\mathrm{FL}$ for 10 minutes in ice bath $\left(0^{\circ} \mathrm{C}\right)$. All treatments remained in turmoil during the exposure to cryoprotectants. 
The PVS2 solution contained $30 \%$ glycerol (v/v), $15 \%$ ethylene glycol ( $\mathrm{v} / \mathrm{v})$ and $15 \%$ of dimethyl sulfoxide - DMSO $(\mathrm{v} / \mathrm{v})$ in MS nutrient medium containing half the concentration of salts and sucrose $0.4 \mathrm{M}(\mathrm{pH}$ 5.7) (Sakai et al., 1990).

\section{Storage and defrosting}

The cryotubes with the treatments were stored in liquid nitrogen under the temperature of $-196{ }^{\circ} \mathrm{C}$ for 30 days. After withdrawing the seeds from liquid nitrogen, the recovery occurred by thawing in a water bath Evlab's appliance, model EV: 015 with accuracy of $0.1{ }^{\circ} \mathrm{C}$, at $40^{\circ} \mathrm{C}$ for $1.5 \mathrm{~min}$. Cryopreservation solutions were removed from cryotubes and the seeds were washed with autoclaved water three times in laminar flow chamber.

\section{Evaluation of the material after defrosting}

Part of the seed batches was submitted to the tetrazolium test for evaluation of the viability of the embryo after freezing, and the other part was arranged in 10 vials (for each treatment) for in vitro cultivation containing MS medium (Murashige and Skoog, 1962) modified with half the macronutrient concentration and $\mathrm{pH}=5.8$, solidified with agar $0.6 \%$. Then they placed in growth room with controlled lighting and temperature for germination.

After 180 days, seed germination was assessed by the frequency of formation of protocorms. After 360 days of germination (DAG), the survival of protocorms, the seedling height, root length and dry mass were also evaluated. Germination was evaluated based on the swelling of seeds and protocorms formation.

\section{Index of proportion between aerial part and root}

Based on the Rules of Seed Analysis (Brasil, 2009) and detailed study of the available literature on phytometric analysis of Orchidaceas, it was possible to evaluate the behavior and development of aerial part and roots of orchids. With the information obtained, we could determine seedlings that considered within normality. Following this assumption, we created an index for this work to identify if the orchid seedlings were within normal parameters, considering the development of the aerial part and root. As a result, it was considered that a normal seedling of Orchidaceas has the ratio of 1:2 (one aerial part to two root parts).

\section{Experimental design}

The experimental design was a completely randomized with two controls, 11 treatments and 10 replications. The data were subjected to analysis of variance (ANOVA), and postassumptions met averages compared by Tukey test to $5 \%$. For statistical effect, the data of the phytometric variables of dry mass of shoots and roots were subjected to BoxCox family of transformation prior to analysis.

\section{Conclusion}

The use of cryoprotectant solutions was assessed for cryopreservation of seeds of Catasetum atratum. The treatment 4 (PVS2 alone) with $67.7 \%$ and treatment 9 (Sucrose + PVS2 + $1 \% \mathrm{FL}$ ) with $69.8 \%$ were those that provided greater survival of seeds and formation of protocorms with $62.0 \%$ and $65.4 \%$, respectively. However, only T4 was indicated for the cryopreservation of this species, as it was the only one that presented germination of seedlings without abnormality within proper shoot and root ratio.

\section{References}

Arigita L, Gonzalez A, Tamés RS (2002) Influence of CO2 and sucrose on photosynthesis and transpiration of Actinia deliciosa explants cultured in vitro. Physiol Plant. 115:166173.

Barros F, Vinhos F, Rodrigues VT, Barbacena FFVA, Fraga CN, Pessoa EM, Guimarães LRS (2015) Orchidaceae in Lista de Espécies da Flora do Brasil. Jardim Botânico do Rio de Janeiro. Retrieved from http:floradobrasil.jbrj.gov.br/jabot/floradobrasil/FB11312. Accessed on June $6^{\text {th }} 2016$.

Brasil (2009) Ministério da Agricultura, Pecuária e Abastecimento. Regras para análise de sementes. Brasília. 399p.

Carneiro LL (2014) Pré-melhoramento genético, floração in vitro e criopreservação de orquídeas nativas do cerrado. Thesis (PhD in Genetics and Plant Breeding) - Universidade Federal de Goiás, Goiânia.

Conselho Nacional de Conservação da Flora - CNCFlora. Informações da avaliação de risco de extinção. Retrieved from http://cncflora.jbrj.gov.br/portal/pt$\mathrm{br} /$ profile/Catasetum\%20atratum. Accessed on July $2^{\text {nd }}$ 2016.

Day JG and Mclellan MR (1995) Protein Phosphatase Protocols: Cryopreservacion and Freezing-Drying Protocols. Humana Press. 208p.

Faria RT, Colombo RC, Oliveira LVR, Camolesi MR (2016) Orquídeas do Gênero Catasetum no Brasil. Londrina: Mecenas. 160p.

Ferreira LS (2014) Cultivo in vitro de orquídeas em dois ambimentes (Sala de crescimento e casa de vegetação): crescimento e capacidade fotossintética. Dissertation (Master in Plant Production) - Universidade Estadual do Norte Fluminense, Campos dos Goytacazes.

Galdiano Junior RF (2013) Criopreservação, indução de poliploidia e avaliação da estabilidade genética de orquídeas. Thesis (PhD in Genetics and Plant Breeding). Faculdade de Ciências Agrárias e Veterinária, Universidade Estadual Paulista, Jaboticabal.

González-Benito EM and Pérez-García F (2001) Cryopreservation of lipid-rich seeds: effect of moisture content and cooling rate on germination. Cryo Letters. 22(2): 135-140.

Holst AW (1999) The world of Catasetum. Timber. Oregon: Humana Press Inc. 306p.

Kerbauy GB (2008) Fisiologia Vegetal. (2nd ed.). Guanabara Koogan. 472p.

Murashige TA and Skoog FA (1962) Revised medium for rapid growth and bioassays with tobacco tissue cultures. Phisiol Plant. 15:473-479.

Pegg DE (2007) Cryopreservation and Freeze-Drying Protocols Methods. In: Molecular Biology. ( $2^{\text {nd }}$ ed.). Humana Press Inc. 348p. 
Pérez-García F and González-Benito EM (2008) Seed cryopreservation of Halimium and Helianthermum species. Cryo Letters. 29:271-276.

Pilatti FK, Aguiar T, Simões T, Benson EE, Viana AM (2010) In vitro and cryogenic preservation of plant biodiversity in Brazil. In Vitro Cellular \& Developmental Biology - Plant. Cheste. 47(1):82-98.

Sakai A, Kobayashi S and Oiyama I (1990) Cryopreservation of nuclear cells of navel orange (Citrus sinensis Osb. var.brasiliensis Tanaka) by vitrification. Plant Cell Rep. 9:30-33.
Souza GRB (2015) Desenvolvimento in vitro e criopreservação de sementes de orquídeas. Thesis ( $\mathrm{PhD}$ in Agronomy). Faculdade de Ciências Agrárias e Veterinária, Universidade Estadual Paulista, Jaboticabal.

Taiz $L$ and Zeiger E (2004) Fisiologia vegetal. 3. ed. Porto Alegre: Artmed, 2004. 722p.

Vendrame WA and Faria RT (2011) Phloroglucinol enhances recovery and survival of cryopreserved Dendrobium nobile protocorms. Sci Hort. 128:131-135.

Vendrame WA, Faria RT, Sorace M and Sahyun SA (2014) Review - Orchid cryopreservation. Ciênc Agrotec. 38(3):213-229. 